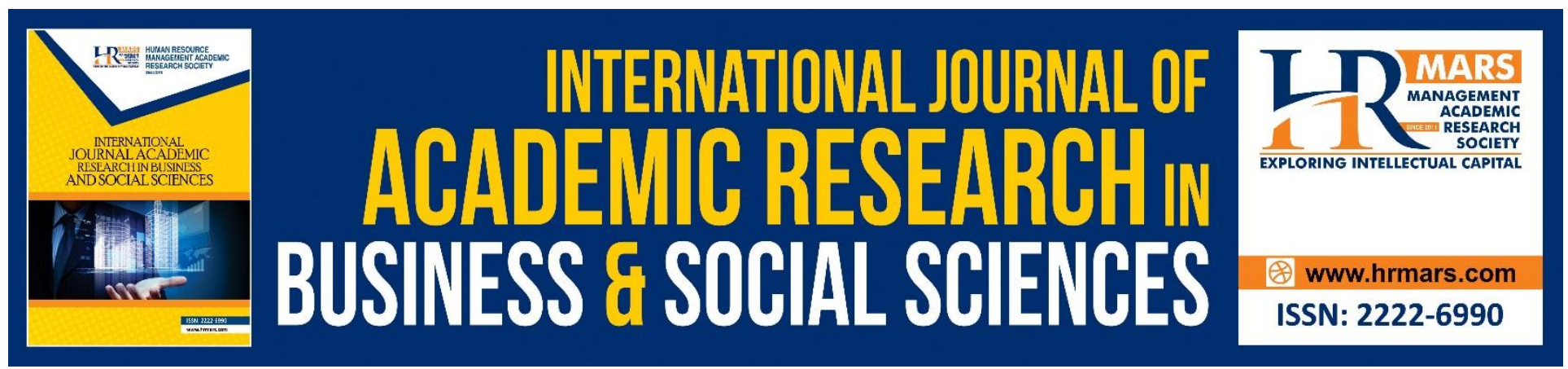

\title{
Business Process Outsourcing Strategy on Competitive Advantage and Organizational Performance
}

\author{
Jones Oghenemega Ejechi, Efosa Abiodun Oshodin
}

To Link this Article: http://dx.doi.org/10.6007/IJARBSS/v9-i6/5987

DOI: $10.6007 /$ IJARBSS/v9-i6/5987

Received: 19 April 2019, Revised: 20 May 2019, Accepted: 07 June 2019

Published Online: 27 June 2019

In-Text Citation: (Ejechi \& Oshodin, 2019)

To Cite this Article: Ejechi, J. O., \& Oshodin, E. A. (2019). Business Process Outsourcing Strategy on Competitive Advantage and Organizational Performance. International Journal of Academic Research in Business and Social Sciences, 9(6), 718-734.

Copyright: (C) 2019 The Author(s)

Published by Human Resource Management Academic Research Society (www.hrmars.com)

This article is published under the Creative Commons Attribution (CC BY 4.0) license. Anyone may reproduce, distribute, translate and create derivative works of this article (for both commercial and non-commercial purposes), subject to full attribution to the original publication and authors. The full terms of this license may be seen at: $\underline{\text { http://creativecommons.org/licences/by/4.0/legalcode }}$

Vol. 9, No. 6, 2019, Pg. 718 - 734

Full Terms \& Conditions of access and use can be found at http://hrmars.com/index.php/pages/detail/publication-ethics 


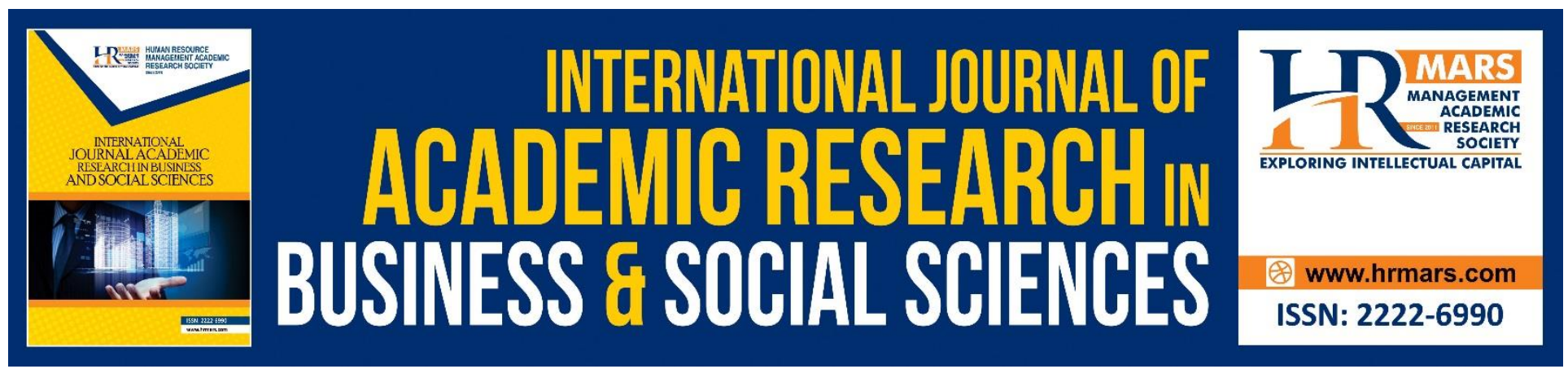

\title{
Business Process Outsourcing Strategy on Competitive Advantage and Organizational Performance
}

\author{
Jones Oghenemega Ejechi, Efosa Abiodun Oshodin* \\ Department of Business Administration, Faculty of Management Sciences, University of Benin, Benin \\ City, Nigeria. \\ Email: abiodun.oshodin@uniben.edu*, Jones.ejechi@uniben.edu
}

\begin{abstract}
This study was set to find the impact of business process outsourcing (BPO) on competitive advantage and organizational performance. This study identified two independent variables (strategic evaluation and relationship management) and four second order constructs (strategic risks evaluation, capability evaluation, relationship commitment and cooperation) of BPO which was then evaluated against competitive advantage and organizational performance. The study in conducting its analysis, a sample size of eighty-six was employed and data was analyzed using Microsoft excel (2010) to code and screen and SMARTPLS3 software for further statistical analysis. The SMARTPLS 3 showed us the casual relationship existing among the different variables. This paper concluded that there exists an indirect relationship between BPO activities and organizational performance. This study recommended that BPO activities should be stepped up by organizations because rather than impacting indirectly on organizational performance, a direct impact will be more significant to the performance of the organization.
\end{abstract}

\section{Introduction}

Innovation, speed, quality, cost and service have been acknowledged as part of the drivers for gaining competitive advantage (Snell \& Bateman, 2014). Globalization has and is still the trending issue that has kept the business organizations on their toes always searching for better ways to achieve performance. In Nigeria, the cost of operating a business is growing daily, unstable government policies, poor infrastructure, poor energy supply, etc. With this kind of factors in the business environment, organizations have searched for better ways to enhance is performance. In reaction to the continuous emphasis on these drivers: cost, quality, service, speed and innovation, organizations have become more flexible by adopting innovative flexible strategies that will redefine the fundamental structure of business process with the sole aim to improve organizational performance 
and staying competitive (Awinon \& Mutua, 2014). This is the new shift in organization thinkingoutsourcing.

Organizations have continuously made effort integrate its supply chains performance by outsourcing part of its business. Outsourcing is a strategy employed by organizations (client) to assign/give the rights and authority to another organization (service provider) to undertake some its activities, usually the non-core activities. In other words, activities that involve strategically delegating part of the business to an independent unit or organization is referred to as outsourcing. These non-core activities outsourced are nonetheless very important for effective realization of the strategic intent of the organization. To the service provider the outsourced activities represents is core business function or specialization. BPO is not an uncommon strategy in Nigeria Organizations, and the decision not to or to engage in outsourcing is that of the management.

This study shifted focus from the reasons or benefits, or the effects and causes of outsourcing to strategic evaluation and relationship management of BPO and how these two factors is related to competitive advantage and organizational performance. Specifically, this work was set out to investigate the influence of BPO strategy on gaining competitive advantage and organizational performance.

\section{Literature Review \\ Organizational Performance}

Organizational performance is a broad concept that has no definite definition rather it encompasses many variables which have been used to define the concept. Categorically, it has been defined to reflect both financial and non-financial measures overtime. Some of the measures used to define the organizational performance include: profit margin on sales, return on investment, growth in sales and investment, competitive positions corporate social responsibility, innovation, responsiveness and employee development and other accounting financial measures. Organizational performance can be said to results measured against targets. Mahapatra (2010) describes the performance of organization as the "ability of an organization to fulfill its mission through sound management, strong governance and a persistent rededication to achieving results". According to Kamanga and Ismail (2016), organization performance is the extent to which the organization achieves a set of predetermined targets that are in line with its mission.

A number of prior studies have measured organizational performance using both financial and market criteria, including return on investment (ROI), market share, profit margin on sales, the growth of ROI, the growth of sales, the growth of market share, and overall competitive position (Zhang, 2001). In line with the above literature, the same items will be adopted to measure organizational performance in this study.

\section{Outsourcing}

Outsourcing came about from the American terminology meaning "outside resourcing" - to get resources from the outside. The National Outsourcing Policy and Institutional Framework of Nigeria, (2007) stated that "outsourcing occurs anytime one enterprise makes a contract with another to perform a process that is normally done internally by the first enterprise". 
Outsourcing requires entering a contract and creating a relationship with a partner to produce goods and or provide services to meet the need of the outsourcing organization. It involves undertaking investments and utilization of resources. According to Weele (2010) outsourcing is divesting ones' resources to achieve a specific need and concentrate on core activities.

\section{Strategic Evaluation}

Strategic evaluation is about firm boundary decisions. It encompasses of what activities should be outsourced, to what extent it should be outsourced and the strategic implication of outsourcing. A comprehensive strategic evaluation of a firm business activity will consider the risks and capabilities (resources) involved. Strategic evaluation is a construct of outsourcing that has been developed, defined, and empirically tested (Lee, Miranda, \& Kim 2004) but its implications on competitive advantage and organizational performance have less being researched on with the exception of Handley and Benton (2009).

By considering the risk and capabilities, strategic evaluation construct will be examined from the risk perspective (strategic risks) and the capability perspective. Theoretically, these constructs have been modeled and explained based on transaction cost theory and the resource based view of the firm (Leiblein \& Miller, 2003) for describing firm boundary decisions made in practice (Handley \&Benton, 2009).

\section{Strategic Risk Evaluation}

This describes the magnitude of the strategic risks involved in outsourcing business processes. Definitely, risks are involved in outsourcing: unveiling of some proprietary information (Gottfredson, Puryear, \& Phillips, 2005) and this has been termed by Walker (1988) as diffusion risk and by Aron, Clemons, and Reddi (2005) as poaching;avoidance of obligation by suppliers which is a function of goals incompatibility and the incapability to monitor all vendors or provider, that is, if the activities is outsourced to more than one provider (Aron et al., 2005); and giving of organization specific assets and incomplete contractual agreement is a risk in outsourcing (Klein,Crawford, \& Alchian, 1978; Williamson, 1979; Holmstro " $\mathrm{m}$ and Roberts, 1998). The transaction cost theory posited that organizations must put into consideration the cost and its resources to effectively and efficiently undertake a business outsourcing activity. That is, all forms, levels and implications of risks associated with outsourcing must be carefully evaluated when deciding to outsource.

\section{Capability Evaluation}

Capability evaluation is the degree to which the capabilities and resources of an organization is evaluated. Insinga and Werle (2000) posited that the evaluation of organizations capabilities is necessary when outsourcing decisions are to be made. Handley and Benton (2009) emphasized organizations must do more than just evaluating its capabilities but must consider the importance of that activity to the strategic intent of the organization. The environment of business is not constant and as such the core capabilities of today will also change and might become non-core in the future. In 2008, Holweg and Pil added that capability evaluation must further consider the prerequisite skills needed in other to gain competitive advantage. The resource based view theory has been used to explain capability evaluation of organizations by stating that when organizations create boundaries. 
INTERNATIONAL JOURNAL OF ACADEMIC RESEARCH IN BUSINESS AND SOCIAL SCIENCES

Vol. 9, No. 6, June, 2019, E-ISSN: 2222-6990 @ 2019 HRMARS

\section{Relationship Management}

Relationship management is basically about creating and maintaining profitable relationships between organizations and vendors. Literature on the support for relationship management abounds (Benton \& Maloni, 2005; Prahinski \& Benton, 2004). In any business activity, the most singular mistake to be made is not been able to maintain relationship with supply chain partners. Healthy relationships promote business activities including outsourcing activities. Relationship management is about people; people make it work by displaying required dispositions.

Business process outsourcing relationship must have a strategic intent (Krstic, 2012) and should include four features according to Saxena and Bharadwaj (2009): depth of relationship, scope of relationship, preferred choice of assets to utilize and business culture. Investing in relationships requires utmost trust and total commitment (Zhao, Huo, Flynn, \& Yeung, 2008). BPO relationships can be said to be characterized by trust and cooperation, and total commitment. This study is focused on relationship commitment and cooperation.

\section{Relationship Commitment}

Relationship commitment according to Prahinski and Benton (2004) is a situation where the client (the outsourcing firm) obligates itself to fulfilling the term and conditions surrounding a stable relationship with the supplier or vendor. It is about making long and short term or continuous sacrifice to adhere to the contractual relationship and or obligations by all supply chain partners. Anderson and Weitz (1992) describe relationship commitment as "a willingness to make short-term sacrifices to maintain the relationship." BPO relationship requires total commitment from all supply chain partners involved especially the top management of the outsourcing firm (Kakabadse \& Kakabadse, 2003). Prahinski and Benton (2004) had a different view of relationship commitment. They saw this relationship as a partnership and as a total system where either the clients or the vendor must maximize the value as a whole rather than maximizing their values independently at the expense of the other.

\section{Business Process Outsourcing in Nigeria}

Organizations in Nigeria today have embraced the business process outsourcing especially in government parastatals due to the continuous advent of IT. IT is most outsourced business activity today especially in the government institutions. BPO have been embraced majorly as a means to cut cost by government in its operations. Particularly among the ministries, institutions, directorates, and agencies, the adoption of BPO may have been driven by the need to comply with the government's policy limiting operations mainly to IT services and other areas classified as back office, front office and middle office (National Outsourcing Policy and Institutional Framework, 2007). Therefore, BPO in Nigeria and by the government may be as a result of a singular objective aimed at eliminating some internal activities to external suppliers whocould undertake them effectively and efficiently.

Outsourcing activities is present in almost all sectors of the country and this is shown in the studies done. For instance, Rajee and Akinlabi (2013) did a study showing outsourcing activity in Nigeria food, beverage, and tobacco industry; Ibukun and Erezi (2015)-the telecommunication industry; Isah, Chikwe and Augustus-Daddie (2017)-microfinance banks in South-East Nigeria; Akinbola, Ogunnaike and Ojo (2013)-fast food industry; Akewushola and Elegbede (2016); Irefin (2012)- Nestle Nigeria; 
INTERNATIONAL JOURNAL OF ACADEMIC RESEARCH IN BUSINESS AND SOCIAL SCIENCES

Vol. 9, No. 6, June, 2019, E-ISSN: 2222-6990 @ 2019 HRMARS

Adeniji (2011)-Nigeria service industry etc. BPO in Nigeria is continuously growing and expanding its scope to include new areas outside the IT.

\section{Framework}

This section provides us with the necessary theoretical underpinning for the relationships among the variables/constructs:

Looking at the risk involved in outsourcing and the required capabilities, organizations must decide on what activities to outsource and what not to. Two theories are pertinent here: the transaction theory and the resource based view theory. The transaction cost theory according to Williamson (1979) the market should be responsible for providing for the cost of goods/services. He further asserted that "it is not possible for a firm to completely contract while incomplete contracts create renegotiations when the balance of power between the transacting parties shifts". Resource based view lies on the premise that resources should be made available to promote organizational success. Information resource can also be externally sourced. Daily, Malton and Cannella (2003) view that the performance of an organization for the achievement of their various objectives is a function of available information to the management.

According to the core competence theory, only core or critical activities should not be outsourced and that by so doing, it will gain competitive advantage by been able to focus on speed (time), quality of its core activities, price etc. It can also be postulated that critical strategic evaluation is associated with competitive advantage.

\section{Research Model and Hypotheses Formulation}

Fig. 1 presents the BPO framework developed in this research. The framework proposes that BPO activities will have an impact on organizational performance both directly and also indirectly through competitive advantage. BPO activities is conceptualized as a four-dimensional construct. The four dimensions are strategic risks (Gottfredson, Puryear, \& Phillips, 2005), capability evaluation (Handley \& Benton, 2009), and relationship commitment (Prahinski \& Benton, 2004). 


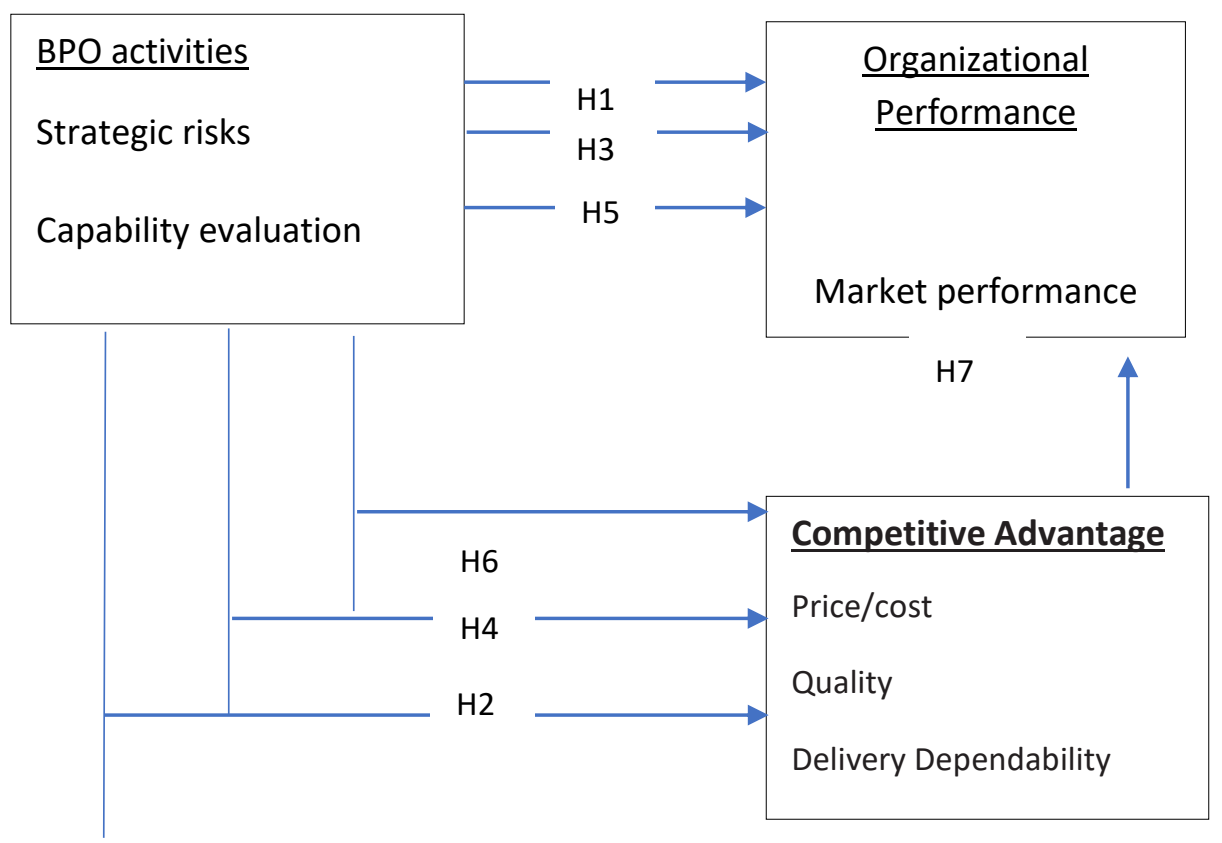

Figure 1: Research framework

Source: Researcher's Construct (2017)

\section{Methodology}

The study adopts the survey research design. The population comprises of all CEOs, directors, managers at different levels in all organizations in Edo State, Nigeria and where CEO's, directors, managers and supervisors were randomly selected to form the sample size. The questionnaire response format is the research instrument meaning that it is a primary data from a primary source. The items generated in the instrument have been and was adopted from validated scales, specifically, strategic evaluation from Handley and Benton (2009); relationship management from Anderson and Weitz (1992) as well as Prahinski and Benton (2004); competitive advantage from Suhong, RaguNathan, Ragu-Nathan, and Subba (2006); and organizational performance from Zhang (2001). This instrument covers the major content of the constructs. The items were constructed using a five-point Likert-type scale ranging from "strongly disagree" to "strongly agree." (See Table 4.3). The questionnaires were administered to potential respondents and other high profile persons whose function is related to outsourcing. The large scale methods of this study was undergone with the aim of choosing respondents that have prerequisite knowledge about business process outsourcing in their organizations. Out of the one hundred (100) targeted respondents' eighty-six (86) responses was returned and found useable for this study with a breakdown of 25 responses from the banking industry, 61 from the brewery industry. The area of expertise was $29 \%$ banking and $71 \%$ brewery. The constructs and items to be used in this analysis were adopted from previously validated 
INTERNATIONAL JOURNAL OF ACADEMIC RESEARCH IN BUSINESS AND SOCIAL SCIENCES Vol. 9, No. 6, June, 2019, E-ISSN: 2222-6990 @ 2019 HRMARS

measures. Because the unit of analysis is at the organizational level, data were collected through a survey of companies belonging to a specific supply chain industry in Nigeria.

The analysis of the data was analyzed using MS Excel version 2010 and SMARTPLS 3. Data was first coded on spread sheet for screening and then imported into SMARTPLS for further analysis. For the moderating effects, AMOS 23.0 was used. The structural equation modeling (SEM) was employed highlighting the causal relationship under investigation. The framework is made of two predictors namely: strategic evaluation and relationship management, one mediating variable, competitive advantage and the outcome variable, organizational performance.

\section{Empirical Analyses and Results}

Analyses and reports of this study is shown below:

\section{Preliminary Data Analyses}

In this section, the data was screened to check for missing values, unengaged responses and ay form of outliers. However, since we are using a five point Likert scale for the items except the bio-data of respondents, there was no presence of outliers. For unengaged responses, we used MS Excel software to carefully identify any form irregular responses. With the use of standard deviation measure, there was no form of unengaged responses. Also there were no missing values above five for each item.

\section{Tests for Measurement Model}

This section contains subsections discussing the statistical analysis employed in determining the confirmatory factor analysis which is the validity and also the reliability of each construct.

\section{Validity and Reliability of Instrument}

The reliabilities and validities of BPO constructs, competitive advantage, and organizational performance were assessed using the quality criteria of SMARTPLS (Cronbach's Alpha). Table 4.1 report Cronbach's Alpha, rho_A, composite reliability and discriminant validity.

Table 4.1: Construct Reliability and Validity

\begin{tabular}{|l|l|l|l|l|}
\hline & Cronbach's Alpha & rho-A & Composite reliability & Discriminant validity \\
\hline CA & 0.72 & 0.741 & 0.839 & 0.797 \\
\hline CE & 0.777 & 0.807 & 0.854 & 0.772 \\
\hline OP & 0.745 & 0.798 & 0.849 & 0.809 \\
\hline RC & 0.72 & 0.793 & 0.833 & 0.792 \\
\hline SR & 0.751 & 0.814 & 0.854 & 0.814 \\
\hline
\end{tabular}

Source: Researchers' computation (2017)

\section{Exploratory}

\section{Factor Analysis}

The Table 4.2 below illustrates a very clean factor structure in which convergent and discriminant validity are evident by the high loadings within factors, and there were cross-loadings between 
factors which have been expunged. The factors demonstrate sufficient convergent validity, as their loadings were all above the 0.700 . Table 4.2 shows the factor loadings for each of the factor.

Table 4.2: Pattern Matrix

\begin{tabular}{|c|c|c|c|}
\hline Item & F1-SR & $\mathrm{F} 2-\mathrm{CE}$ & $\mathrm{F} 3-\mathrm{RC}$ \\
\hline \multicolumn{4}{|l|}{ (a)BPO } \\
\hline $\mathrm{BPO} / \mathrm{SR} 3$ & 0.818 & & \\
\hline $\mathrm{BPO} / \mathrm{SR} 4$ & 0.736 & & \\
\hline BPO/SR5 & 0.880 & & \\
\hline BPO/CE1 & & 0.733 & \\
\hline BPO/CE2 & & 0.822 & \\
\hline BPO/CE3 & & 0.735 & \\
\hline BPO/CE4 & & 0.792 & \\
\hline $\mathrm{BPO} / \mathrm{RC} 3$ & & & 0.805 \\
\hline $\mathrm{BPO} / \mathrm{RC} 4$ & & & 0.86 \\
\hline $\mathrm{BPO} / \mathrm{RC5}$ & & & 0.701 \\
\hline Item & F1-DD & $\mathrm{F} 2-\mathrm{QL}$ & \\
\hline \multicolumn{4}{|c|}{ (b) Competitive Advantage } \\
\hline CA/DD3 & 0.768 & & \\
\hline CA/QL3 & & 0.847 & \\
\hline CA/QL4 & & 0.774 & \\
\hline Item & F1-MP & & \\
\hline \multicolumn{4}{|c|}{ (c) Organizational Performance } \\
\hline OP3 & 0.882 & & \\
\hline OP2 & 0.823 & & \\
\hline OP3 & 0.711 & & \\
\hline
\end{tabular}

Source: Researchers' computation (2017)

\section{Confirmatory factor analysis}

Model fit

All the constructs have items with significant loadings $\geq 0.70$. Modification indices was not consulted as the model was improved, that is, none of the error term were covaried. The Table 4.3below indicates that the goodness of fit for our measurement model is sufficient. 
INTERNATIONAL JOURNAL OF ACADEMIC RESEARCH IN BUSINESS AND SOCIAL SCIENCES

Vol. 9, No. 6, June, 2019, E-ISSN: 2222-6990 @ 2019 HRMARS

Table 4.3: Goodness of fit statistics in CFA

\begin{tabular}{|l|l|l|l|l|}
\hline Indices & Abbreviation & $\begin{array}{l}\text { Observed } \\
\text { values }\end{array}$ & $\begin{array}{l}\text { Recommended } \\
\text { criteria }\end{array}$ & References \\
\hline Chi square & $\chi 2$ & 52.967 & pval $>0.05$ & $\begin{array}{l}\text { Hair, Black, Babin, Anderson, } \\
\text { and Tatham (2010) }\end{array}$ \\
\hline Normed chi square & $\chi 2 / D F$ & 1.826 & $1<\chi 2 / \mathrm{df}<3$ & Byrne (2010) \\
\hline Goodness-of-fit index & GFI & 0.901 & $>0.90$ & Hu and Bentler (1999) \\
\hline Adjusted GFI & AGFI & 0.792 & $>0.80$ & Jöreskog and Sörbom (1993) \\
\hline Normed fit index & NFI & 0.923 & $>0.90$ & \\
\hline Comparative fit index & CFI & 0.970 & $>0.95$ & \\
\hline $\begin{array}{l}\text { Root mean square error } \\
\text { of approximation }\end{array}$ & RMESA & 0.060 & $\begin{array}{l}<0.05 \text { good fit } \\
<0.08 \text { acceptable } \\
\text { fit }\end{array}$ & \\
\hline Tucker-Lewis index & TLI & 0.854 & $0<T L 1<1$ & \\
\hline
\end{tabular}

Source: Researchers' computation (2017)

\section{Results for the Structural Model}

The theoretical framework illustrated in Fig. 1shows the hypothesized relationships among the variables BPO (strategic risks, capability evaluation, and relationship commitment), competitive advantage, and organizational performance. Fig. $2 \& 3$ displays the path diagram resulting from the structural modeling analysis using SMARTPLS. The results exhibit that all the measurements have significant loadings to their corresponding second-order construct. Overall, the model has a satisfactory fit with SRMR (Standardized Root Mean Residual) $=.053$. This is a good fit as it is below .08. Also, the VIF's (Variance Inflator Factor) also called collinearity statistics is all below 3 indicating that our model is reliable. The VIF measures how much the variance of an estimated regression coefficient increases if your predictors are correlated. The rule of thumb is that if VIF is below 3 , then our model is reliable. Finally, in our quality criteria, when the NFI (Normed Fit Index) is greater than 0.9 it is assumed the model is satisfactory (Awang, 2012). In our case, our NFI is 0.97 which means our model is satisfactory. 


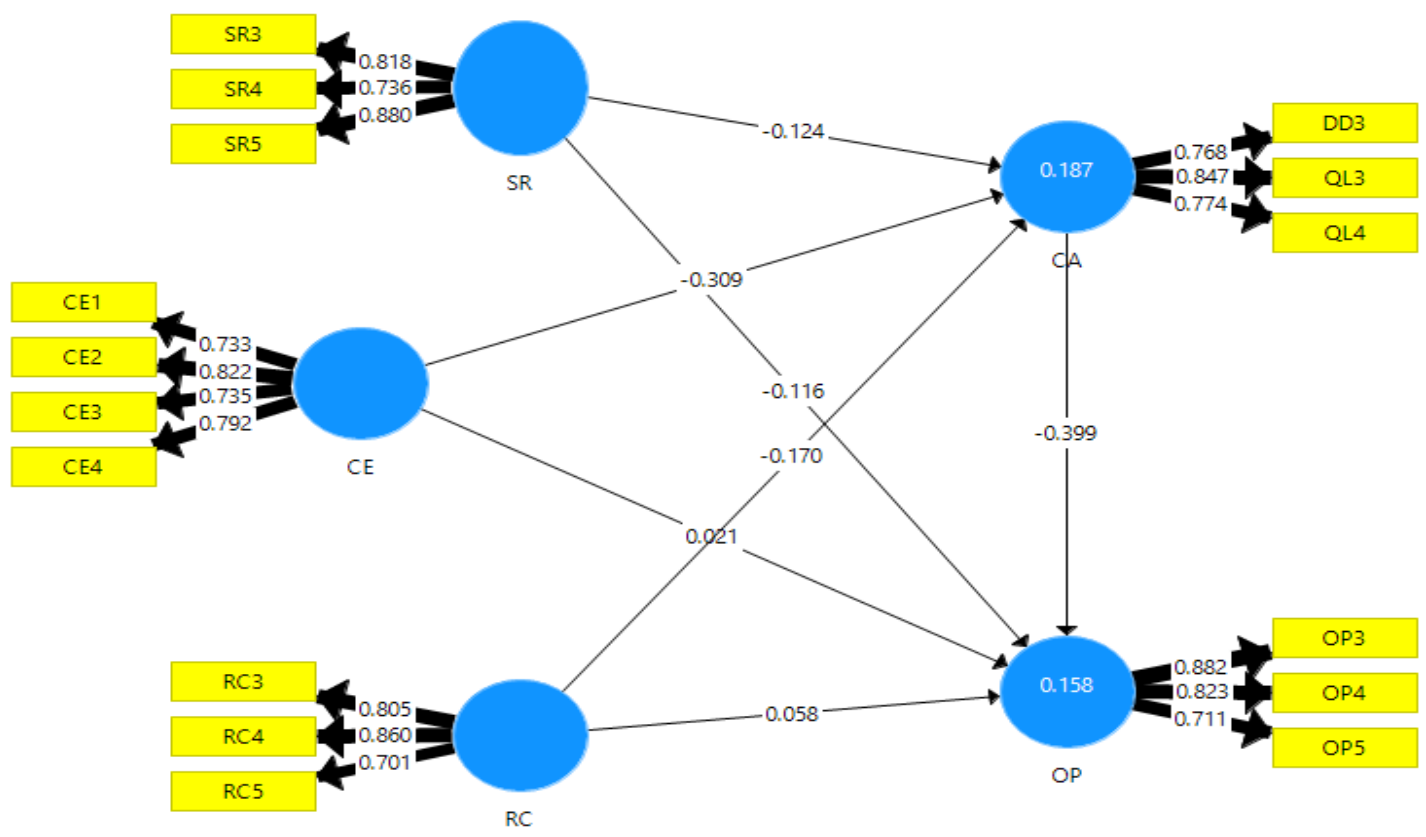

Fig. 2: PLS Algorithm (Path weighting) SRMR=0.053, VIF's $<3, \mathrm{NFI}=0.97$

The result in figure 2 shows the different loadings are all above 0.07 meaning each item has significant loading. The arrow shows the loadings of each item; the thicker the arrow, the higher the relative values (loadings). Loadings not appearing in the figure below indicates that such item have may not be a strong indicator of BPO. 


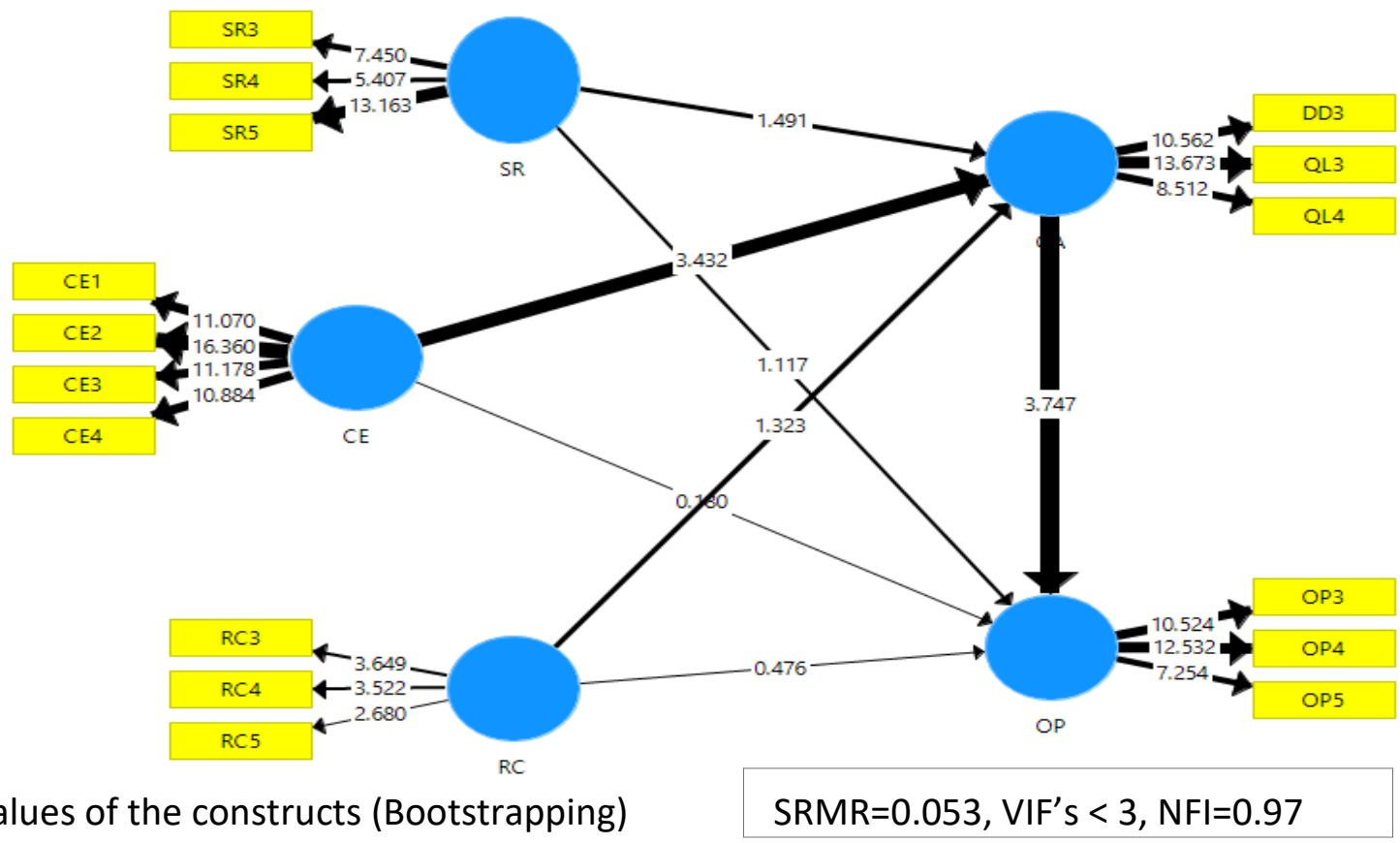

Fig. 3: T-values of the constructs (Bootstrapping)

A look at fig. 3 shows that some paths weights are significant, that is, the t-values are above 1.96 . However, the relationship between the variables shows that some are significant and others are not. Only two relationships between the variables are significant with values higher than 1.96 and they are the relationship between capability evaluation and competitive advantage; and the relationship between competitive advantage and organizational performance. There is no direct effect of BPO on organizational performance, rather there is an indirect effect flowing from capability evaluation to competitive advantage and to organizational performance. The result shows that strategic risk is a stronger indicator of organization performance despite been not significant and also to gaining competitive advantage, quality is a stronger indicator, while for organizational performance, the growth of sales is the highest indicator than the other dimensions.

\section{Test of Hypotheses}

The results of the proposed structural equation model analysis are presented in Table 5 indicating support for two of the hypotheses. Table 5 shows the output of the causal relationship between the variables. The result tells us the position of study. Also in the table are the t-values which indicates whether our findings with respect to each hypotheses is significant or not. For Hypothesis 1, our report shows that there is no significant relationship between strategic risk and organizational performance. This is so because our t-value is below 1.96 and our p-value is above 0.05 level of significance. 
INTERNATIONAL JOURNAL OF ACADEMIC RESEARCH IN BUSINESS AND SOCIAL SCIENCES

Vol. 9, No. 6, June, 2019, E-ISSN: 2222-6990 @ 2019 HRMARS

Table 5: Result for proposed structural equation model

\begin{tabular}{|l|l|l|l|l|l|l|}
\hline Hypothesis & Relationship & Total effects & Direct effects & $\begin{array}{l}\text { Indirect } \\
\text { effects }\end{array}$ & T-statistics & P-values \\
\hline H1 & SR-OP & -0.046 & $-0.095(1.277)$ & $0.049(1.322)$ & 0.639 & 0.523 \\
\hline H2 & CE-OP & 0.145 & $0.022(1.441)$ & $0.123(2.616)$ & 1.268 & 0.205 \\
\hline H3 & RC-OP & 0.126 & $0.058(0.476)$ & $0.068(1.218)$ & 0.925 & 0.355 \\
\hline H4 & SR-CA & -0.124 & $-0.124(1.495)$ & & 1.495 & 0.136 \\
\hline H5 & CE-CA & -0.309 & $-0.309(3.187)$ & & 3.187 & 0.002 \\
\hline H6 & RC-CA & -0.17 & $-0.170(1.330)$ & & 1.330 & 0.184 \\
\hline H7 & CA-OP & -0.39 & $-0.399(4.057)$ & & 4.057 & 0.000 \\
\hline SRMR $=0.053$ VIF $<3$ & & & & & \\
\hline
\end{tabular}

Source: Researchers' computation (2017)

Table 6: Result for proposed structural equation model (specific indirect effects)

\begin{tabular}{llllll}
\hline & Original & & & & P \\
Relationship & Sample & Sample Mean & Standard Dev. & T statistics & values \\
\hline CE-CA-OP & 0.123 & 0.128 & 0.045 & 2.751 & 0.006 \\
RC-CA-OP & 0.068 & 0.076 & 0.055 & 1.241 & 0.215 \\
SR-CA-OP & 0.049 & 0.049 & 0.035 & 1.395 & 0.164 \\
SRMR $=053$ & VIF $<3$ & & & & \\
\hline
\end{tabular}

Source: Researchers' computation (2017)

The statistical insignificance of Hypothesis 1 confirms that BPO effort particularly the strategic evaluation has no influence on organizational performance. This is so because outsourcing in banks is majorly on security and cleaning services, while outsourcing in breweries is particularly about crates production and distribution. So it is almost not possible to outsource their core activities, and for the activities outsourced to threaten their primary existence.

Hypothesis 2 is unsupported which indicates that capability evaluation does have a direct impact on organizational performance. The result shows that there is t-value is less than 1.96 and $P>05$. By implication, this shows how much importance is the weight and level of the outsourced activities. Considering the capability evaluation of the organizations undertaking the activities is not a primary to the outsourcing organization.

Hypothesis 3 also provides that there exists no significant relationship between relationship commitment and organizational performance. That is to say, relationship commitment does not influence organizational performances of these companies because our report showed that the standardized coefficient is 0.126 which is not statistically significant at $P<.05(t=0.925)$.

Also unsupported is Hypothesis 4, where strategic risk does not impact on competitive advantage with $\mathrm{P}<0.5$ and $t=1.495$. Hypothesis 5 , indicates that there exists a significant relationship between capability evaluation and competitive advantage. The standardized coefficient is -0.309 which is statistically significant at $P<.05(t=3.187)$. The result indicates that capability evaluation affects competitive advantage. That is, the consideration of risks associated with outsourcing is less important compared to the consideration of the capability of the outsourcing activity. 
Also unsupported is Hypothesis 6 , where relationship commitment does not impact on competitive advantage $(P>0.05$ and $t=1.335$. For Hypothesis 7 , the results support that competitive advantage will impact on organizational performance. The standardized coefficient is -0.397 which is statistically significant at $P<.05(t=3.747)$. This analysis reports that our mediating variable, 1competitive advantage is the only variable that has a direct impact on organizational performance

Based on the standardized coefficients of the seven hypotheses displayed in Table 5, relationship commitment may have a greater direct impact on competitive advantage $(t=1.330)$ than strategic risk ( $t=1.495)$ on competitive advantage. Also, strategic risk is shown to have more impact even though not significant on organizational performance $(t=0.639)$ than capability evaluation ( $t=1.268)$ and relationship commitment ( $t=0.925$ ) on organizational performance. This could be true since organizational performance is usually influenced by many factors and it is hard to see whether anyone factor, such as BPO constructs will dominantly determine the overall performance of an organization.

The standardized coefficient of the indirect effect of strategic evaluation and relationship management on organizational performance is $0.049(t=1.395)$ and $0.068(t=1.241)$ respectively which is significant at 10 level (for strategic evaluation only). Our analysis from Table 5thus shows that BPO can have a direct, positive and negative influence on organizational performance as well as an indirect one through competitive advantage.

In Table 6, the specific indirect impact that BPO has on organizational performance is through capability evaluation which leads to competitive advantage and to organizational performance. This indicates that BPO practices produce competitive advantage to the organization in the first place, and competitive advantage will, in turn, lead to improved organizational performance. In literature, BPO constructs, mostly, have been linked directly to organizational performance. The findings of this research indicate the presence of an intermediate measure of competitive advantage between BPO and organizational performance. Among the three relationships, only CE-CA-OP was found significant at 0.05 level $(t=2.751)$

The study focuses on the causal relationships between BPO, competitive advantage and organizational performance. It is possible that enhanced competitive advantage and increased organizational performance could have improved the levels of BPO activities. The increased competitiveness of a firm may enable a firm to implement higher level of BPO due to the need to outperform its competitors constantly and keep its competitive position in today's dynamic business world. On the other hand, enhanced organizational performance provides a firm increased capital to implement various BPO activities. Likewise, enhanced organizational performance could have increased the competitive advantage of a firm.

\section{Discussion of Findings}

Although some organizations have realized the importance of implementing BPO, they often do not know exactly what to implement, due to a lack of understanding of what should or should be outsourced and how much capabilities do both parties have. By proposing, developing, and validating a multi-dimensional, operational measure of the construct of BPO, and by demonstrating its efficacy in enhancing organizational performance and competitive advantage, the present study provides 
CEOs, Directors, Managers and others involved in outsourcing activities with a useful tool for evaluating the comprehensiveness of their current BPO activities.

We have shown that BPO forms a second-order construct composed of the first-order constructs of strategic risks evaluation, capability evaluation, relationship commitment and cooperation- the four major components of BPO consideration. Through the analysis of the relationship of BPO constructs with competitive advantage, it was demonstrated that BPO may directly impact competitive advantage and indirect impact on organizational performance through competitive advantage. This supports the findings of Prahinski and Benton (2004); Handley and Benton (2009), in that they concluded that BPO activities impact on organizational performance directly and indirectly. The findings of this research thus point to the importance of BPO to the organizations. With rapid change for development and the speed of technological advancements, organizations rather than concentrating its efforts on everything about what it does, they tend to outsource non and or less critical activities in order to meet up and surpass their competitors. By surpassing competitors, the organization has placed itself in a position of gaining competitive advantage which it has to maintain continuously.

\section{Conclusion and Recommendations}

This paper provided empirical justification for a framework that identified four key dimensions of BPO and describes the relationship among BPO, competitive advantage, and organizational performance. It examined five hypotheses which in the process assessed the validity and reliability of the instrument used. This study provided empirical evidence to support conceptual and prescriptive statements in the literature regarding the impact of BPO. This paper concluded that there exists an indirect relationship between BPO activities and organizational performance. This study recommended that BPO activities should be stepped up by organizations because rather than impacting indirectly on organizational performance, a direct impact will be more significant to the performance of the organization.

\section{References}

Akewushola \& Elegbede, (2013). Outsourcing strategy and organizational performance: Empirical evidence from Nigeria manufacturing sector. European Journal

Akinbola, O., Ogunnaike, O., \& Ojo, O. (2013). Enterprise outsourcing strategies and marketing performance of fast food Industry in Lagos State, Nigeria. Global Journal of Business Management and Accounting, 3(1), 22-33.

Anderson, E., \& Weitz, B., (1992). The use of pledges to build and sustain commitment in distribution channels. Journal of Marketing Research, 29(1), 18.

Aron, R., Clemons, E. K., \& Reddi, S., (2005). Just right outsourcing: understanding and managing risk. Journal of Management Information Systems, 22(2), 37-55.

Awinon, Z., \& Mutua, M. (2014). Business process outsourcing strategy and performance of Kenyan state corporations. Journal of Emerging Trends in Economics and Management Sciences, 5(7): 37-43.

Benton, W. C., \& Maloni, M., (2005). The influence of power driven buyer/seller relationships on supply chain satisfaction. Journal of Operations Management, 23(1), 1-22. 
INTERNATIONAL JOURNAL OF ACADEMIC RESEARCH IN BUSINESS AND SOCIAL SCIENCES Vol. 9, No. 6, June, 2019, E-ISSN: 2222-6990 @ 2019 HRMARS

Byrne, B. (2010). Structural Equation Modeling with AMOS. Routledge, Taylor \& Francis Group, New York.

Daily, C. M., Malton, R. D., \& Cannella, A. A. (2003). Corporate governance: Decades of dialogue and data. Academy of Management Review, 28.

Gottfredson, M., Puryear, R., \& Phillips, S., (2005). Strategic sourcing from periphery to the core. Harvard Business Review, 83(2), 132-139.

Hair, J., Black, W., Babin, B., Anderson, R., \& Tatham R. (2010). Multivariate Data Analysis. 7th edth. Pearson Prentice Hall, UpperSaddle River

Handley, S., \& Benton, W. (2009). Unlocking the business outsourcing process model. Journal of Operations Management, 27, 344-361.

Holmstrom, B., \& Roberts, J., (1998). The boundaries of the firm revisited. Journal of Economic Perspectives, 12(4), 73-94.

Holweg, M., \& Pil, F., (2008). Theoretical perspectives on the coordination of supply chains. Journal of Operations Management, 26(3), 389-406.

Hu, L., \& Bentler, P. (1999) Cutoff criteria for fit indexes in covariance structure analysis: conventional criteria versus new alternatives. Struct Equ Model: Multidiscip J. 6(1):1-55.

Ibukun, K., \& Erezi, A. (2015). Achieving organizational performance through business process outsourcing. European Scientific Journal, 11(4), 457-473.

Insinga, R.C., \& Werle, M.J., (2000). Linking outsourcing to business strategy. Academy of Management Executive, 14(4), 58-70.

Irefin, A., \& Olateju, O. (2012). Effect of outsourcing strategy on project success. Transnational Journal of Science and Technology, 2(6), 128-143.

Isah, A., Chikwe, C., \& Augustus-Daddie, J. (2017). Outsourcing as a strategic option to organizational effectiveness: A study of selected micro-finance banks in Southeast Nigeria. Journal of Applied Management Science, 3(2), 92-102.

Joreskog, K., \& Sorbom, D. (1993). LISREL 8. Scientific Software International, Chicago.

Kakabadse, A., \& Kakabadse, N., (2003). Outsourcing best practice: transformational and transactional considerations. Knowledge and Process Management, 10(1), 60-71.

Kamanga, N, \& Ismail, N. (2016). Effects of outsourcing on organization performance in manufacturing sector in Kenya: A case of Del Monte Kenya limited.European Journal of Logistics, Purchasing and Supply Chain Management, 4(3), 32-58.

Klein, B., Crawford, R.G., \& Alchian, A.A., (1978). Vertical integration, appropriable rents, and the competitive contracting process. Journal of Law \& Economics, 21(2), 297-326.

Krstic, B. (2015). Business process outsourcing as a tool for improving enterprise efficiency. Scientific Review Article, 61(3), 31-41.

Lee, J. L., Miranda, S. M., Kim, \& Y. M., (2004). IT outsourcing strategies: universalistic, contingency, and configurational explanations of success. Information Systems Research, 15(2), 110-131.

Leiblein, M. J., \& Miller, D. J., (2003). An empirical examination of transaction and firm-level influences on the vertical boundaries of the firm. Strategic Management Journal, 24(9), 839859.

Mahapatra, B. (2010), Human Resource management. New Delhi: New Age International (P) Limited. National Outsourcing Policy and Institutional Framework for Nigeria, (2007). 
INTERNATIONAL JOURNAL OF ACADEMIC RESEARCH IN BUSINESS AND SOCIAL SCIENCES

Vol. 9, No. 6, June, 2019, E-ISSN: 2222-6990 (C) 2019 HRMARS

Prahinski, C., \& Benton, W.C., (2004). Supplier evaluations: communication strategies to improve supplier performance. Journal of Operations Management, 22(1), 39-62.

Rajee, F., \& Akinlabi, B. (2013). Outsourcing services as a strategic tool for organizational performance: An exploratory study of Nigerian food, beverage, and tobacco industry. Journal of Management Policies and Practices, 1(1), 1-20.

Saxena, K., \& Bharadwaj, S. (2009). Managing business process through outsourcing: A strategic partnering perspective. Business Process Management Journal, 15(5), 687-715.

Suhong, L., Ragu-Nathan, B., Ragu-Nathan, T., \& Subba, S. (2006). The impact of supply chain management practices on competitive advantage and organizational performance. Retrieved from www.elsevier.com/locate/omega

Walker, G., (1988). Strategic sourcing, vertical integration, and transaction costs. Interfaces, 18(3), 62-73.

Weele, A. J. (2010). Purchasing and Supply Chain Management: Analysis, Strategy, Planning and Practice. Hampshire: Cengage learning EMEA.

Williamson, O.E., (1979). Transaction-cost economics: the governance of contractual relations. Journal of Law and Economics, 22(2), 233-261.

Zhang, Q. (2001). Technology infusion enabled value chain flexibility: A learning and capability-based perspective. Doctoral dissertation, University of Toledo, Toledo, $\mathrm{OH}$.

Zhao, X., Huo, B., Flynn, B., \& Yeung, J., (2008). The impact of power and relationship commitment on the integration between manufacturers and customers in a supply chain. Journal of Operations Management, 26(3), 368-388. 